\title{
CAN ISLAMIC MICROFINANCE ALLEVIATES POVERTY IN INDONESIA? AN INVESTIGATION FROM THE PERSPECTIVE OF THE MICROFINANCE INSTITUTIONS
}

\author{
Adhitya Ginanjar ${ }^{1}$ and Salina Kassim ${ }^{2}$ \\ ${ }^{1}$ International Islamic University Malaysia, Malaysia, adhitya@uinjkt.ac.id \\ ${ }_{2}^{2}$ International Islamic University Malaysia, Malaysia, ksalina@iium.edu.my
}

\begin{abstract}
This study examines the poverty alleviation efforts undertaken by the Islamic microfinance institutions (IMFIs) in Indonesia. We focused on the role played by the IMFIs in view of their direct involvements in the process of dealing with the borrowers, and their better understanding about the financial inclusion agenda as well as the financial guidelines and regulations issued by the relevant authorities. In methodology, a total of 34 managers of Baitul Maal wat Tamwil (BMTs) were taken as respondents from the Jakarta, Bogor, Depok, Tangerang and Bekasi (JABODETABEK) areas. A two-step approach was adopted in arriving at enriching findings: first, a survey questionnaire was distributed to the respondents, and subsequently, an in-depth interview was conducted to outline data related to the model design. The findings of this study highlight specific dimensions to improve financial inclusion among the poor. Apart from providing important inputs for better decision-making for the BMTs to further enhance its role in poverty alleviation, this study suggests a variety of strategies to warrant success of poverty alleviation efforts by BMT.
\end{abstract}

Keywords: Financial inclusion, Islamic microfinance institutions, Baitulmaal wa tamwil, Islamic finance, Indonesia. JEL Classifications: G21; G23; G28; G41; I32; I38.

\author{
Article history: \\ Received : October 15, 2018 \\ Revised : : December 25, 2019 \\ Accepted : January 8, 2020 \\ Available online : February 28, 2020 \\ https://doi.org/10.21098/jimf.v6i1.1203
}




\section{INTRODUCTION}

\subsection{Background}

According to the World Bank Global Financial Index (2011), about half of the adults in the developing countries have no access to basic financial services as they are considered as "un-bankable" from the perspective of the mainstream finance. In the absence of access to financial capital, the poor are unable to improve their socio-economic standing and has remained in poverty. The United Nations (UN) through the Sustainable Development Goals (SDGs) suggested that poverty can be alleviated by improving financial access to the poor. Of the listed 17 goals under the SDGs, ending poverty and ensuring universal financial access to all through improving financial inclusion are highly relevant in the context of many developing countries, including Indonesia. By having better access to financial resources and services, the poor are able to effectively utilize their physical resources in efforts to achieve economic independence. Thus, improving financial inclusion has been set as a global agenda, especially in the developing countries.

Along with the agenda of achieving universal financial access by 2030, the role of all types of financial institutions, particularly the microfinance institutions (MFIs) in expanding their services has becoming imminent (World Bank, 2014; Beck, Senbet, \& Simbanegavi, 2015). Microfinance has been proposed to be an effective method to alleviate extreme poverty and offer positive welfare impact through its role in improving the long-term income of the poor. Several studies have also shown that providing accessibility to credit for the microenterprises does not only provide effective solutions to poverty, but it also works well for the clients, who are close to the poverty line since it will provide them with the chance to be economically independent and breaking the poverty trap. Through microfinance, poverty can be reduced by providing credit to the poor or by permitting them an access to credit. In this regard, the role of Islamic MFIs has also been increasing, particularly leveraging on its unique aspects such as the noble Islamic values and relating it to financial policies that could benefit the poor people.

In the case of Indonesia, microfinance has been an effective tool in alleviating poverty due to the limited access to financial services among the poor who accounted for approximately 96 million of the Indonesian population (or approximately 37 percent of the total population). Living on less than USD 1.90 per day, the poor are considered too risky to be given credit facilities by the formal financial services providers, especially due to the absence of collateral and steady income. Their lifestyle peculiarities such as illiteracy and living in remote areas have also limited their access to formal financial services. The Islamic MFIs, in particular, have been playing an important role in the poverty alleviation program in Indonesia especially since 2000 . The Islamic MFIs help in alleviating poverty by providing financial services to the poor in the informal sector of the economy, and are usually funded using Islamic social fund such as zakat, infaq, sadaqah and waqf. Islamic microfinance is basically interest-free microfinance as it delivers funding without the interest so as to comply with the Islamic financing principles (Dhumale and Sapcanin, 1998; Wulandari and Kassim, 2016). One of the well-known Islamic MFIs in Indonesia is the Baitulmaal Wa Tamwil (BMT), which has been conducting and delivering their businesses based on the principles of Islamic muamalat. Operating based on a cooperative model, the BMT has two functions, namely social function 
(Baitulmaal) and business function (Baituttamwil), simultaneously. According to the Indonesian Ministry of Cooperative and Micro, Small and Medium Enterprises (2017), currently, there are more than 5,000 BMTs around Indonesia, and this Islamic MFI has contributed significantly to the income of the poor, helping them to graduate from poverty and improving their wealth (Santoso \& Ahmad, 2016). It is estimated that cooperative, in general, has contributed around $4 \%$ to the Indonesian gross domestic product (GDP). However, the research explanatories of role of IMFIs in alleviating poverty have not been more observed explicitly from perspective of Islamic microfinance institutions.

\subsection{Objective}

The BMT has grown significantly over the last 20 years and it continues to improve the wealth and alleviate poverty among the poor in the country. Mislan and Ismail (2014) stated that the BMT is capable in collecting and developing social funds such as zakat and corporate social responsibility (CSR), while simultaneously could help to increase members' awareness to increase zakat and CSR fund for financing people and increasing wealth. Furthermore, musharakah funding has become a real transaction based on Islamic profit and lost sharing compared to conventional institutions such as risk sharing, ukhuwah (brotherhood), and ta'awun (helping each other). Hence, BMT has dual functions comprising social function and profit function in improving financial inclusion in Indonesia (Ismail, 2014). According to Santoso and Ahmad (2016), among the factors contributing to the success of BMTs in assisting the poor and improving their income are the high commitment and perseverance of the stakeholders of the BMTs. Continuous efforts are made to understand the background, vision, mission and shari'ah principles guiding the operation of the BMT. As such, a comprehensive education for the stakeholders of BMT is very important in improving financial inclusion in Indonesia. Therefore, this study objectives to suggest a variety of strategies to warrant success of poverty alleviation efforts by BMT and observes the determinants which influence IMFIs in alleviating poverty.

\section{LITERATURE REVIEW}

\subsection{Background Theory}

In accordance with goal of financial inclusion which is alleviating poverty, it is important to understand the dominant factors, relevant policies and regulatory compliance which influence the role of the Islamic microfinance institutions in achieving their goals. Alleviating poverty through Islamic microfinance needs to be related to the existence and nature of the Islamic MFIs.

\subsubsection{Islamic Microfinance}

Microfinance is known to be one of the best tools to combat poverty, as it allows the poor to empower both themselves and their communities through the creation and sustainment of their own businesses. Moreover, green microfinance, which combines the core concepts of microfinance with environmental awareness 
and preservation, aims to allow empowerment to occur without compromising the environment. Microfinance institutions (MFIs) use simple administrative procedures and the general abolishment of collateral to allow inhabitants of remote areas to access microfinance, whilst maintaining relationships with them and assisting with their financial and personal problems, educating them, and providing aid in the event of environmental disasters. Hence, microfinance is believed to have a positive effect on both poverty alleviation and environmental awareness (Effendi, 2013).

According to Effendi (2013), in Indonesia, the country with the biggest Muslim population in the world, Islamic finance, which was established in 1991 and saw rapid development during the politically volatile years of 1997 and 1998, comprises commercial banks and banking units, Islamic rural banks, and Islamic financial cooperatives. While the commercial Islamic banks focus on providing savings, financing, and insurance mainly to the medium and large businesses, those running small or micro-businesses are restricted from receiving their services. Islamic microfinance (IMFI), in the form of banking units, rural banks, and financial cooperatives, fills the void left by the commercial banks, enabling Indonesia's disadvantaged entrepreneurs to generate income on their own terms.

According to Ministry of Cooperative and Micro, Small, Medium Enterprises (2017), there are 152,714 cooperatives in Indonesia which are being categorized as MFIs. The detailed breakdown of the MFIs can be seen on following Table 1. Of the total 23,551 MFIs in the country, 5,648 are Islamic MFIs (accounting for about 24 percent), while 17,903 (or 76 percent) are conventional MFIs. Despite relatively small in number compared to the conventional MFIs, the Islamic MFIs are playing an increasing role in increasing financial inclusion among the poor in Indonesia.

Table 1.

Cooperatives in Indonesia

\begin{tabular}{llcc}
\hline No & \multicolumn{1}{c}{ Categories } & Unit & Percentage (\%) \\
\hline 1. & IMFI/Islamic Cooperative & 5,648 & 23.98 \\
2. & MFI/Conventional Cooperative & 17,903 & 76.90 \\
\hline & Total Microfinance Institution & $\mathbf{2 3 , 5 5 1}$ & $\mathbf{1 5 . 5 8}$ \\
\hline 3. & Producing Cooperative & 27,179 & 17.98 \\
4. & Marketing Cooperative & 3,091 & 2.04 \\
5. & Consumer Cooperative & 94,332 & 62.40 \\
6. & Services Cooperative & 3,025 & 2.00 \\
\hline Total Non-Microfinance Institutions & 127,627 & 84.42 \\
Total Cooperatives in Indonesia & $\mathbf{1 5 2 , 7 1 4}$ & $\mathbf{1 0 0}$ \\
\hline
\end{tabular}

Source: Ministry of Cooperative and Micro, Small, Medium Enterprises (2017).

The need to employ Islamic principles in Islamic finance, such as avoiding riba, gharar, jahl, darar, and other unfair business practices, does not mean Islamic MFIs have limited financial products. Islamic microfinance employs several methods of fund mobilization and financing, and uses a monitoring system for managing risk (Obaidullah and Khan 2008). The Islamic microfinance is able to benefit from more diversified sources of funds such as zakat, infaq, and sadaqah, 
whereas conventional microfinance does not have access to these capital sources. However, conventional microfinance can use interest as a method of increasing income, while Islamic microfinance is instead required to provide other schemes that still remain compliant with Islamic laws (Rahim \& Rahman, 2007).

\subsubsection{Financial Inclusion and Alleviation of Poverty Issues}

The concept of financial inclusion was initiated by the World Bank in Global Financial Development Report (2014):

"Financial inclusion has been shown to be an effective way to access the financial services and its objectives of financial inclusion are for reducing poverty and boosting shared prosperity. The goals of financial inclusion for accessing financial service in rural area, saving money, having financial literacy and covering by insurance."

Financial inclusion initially moves up into global reform agenda and becomes a topic of great interest for policy makers, regulators, researchers, and market practitioners. Other studies give definition to financial inclusion. The modest definition of financial inclusion came from Alliance for Financial Inclusion (AFI), a Non-Government Organization (NGO) institution being established which is supported by World Bank highlighted that "financial inclusion is no longer a fringe subject, it is now recognized as an important part of the mainstream thinking on economic development based on country leadership" (IMF-World Bank Spring Meetings, 2013). Moreover, financial inclusion is also stated to as a condition in which government implements policies and practices, revealing diversity in the efforts towards achieving financial inclusion and implementing a progressive approach in financial inclusion (Arun \& Kamath, 2015).

(Allen, Demirguc-Kunt, Klapper, \& Martinez Peria, 2016), to further understand this concept, financial inclusion include six important aspects, namely: (i) it is important for development and poverty reduction; (ii) it does not mean finance for all at all costs; (iii) the focus of public policy should be on addressing market failures; (iv) new technologies hold promise for expanding financial inclusion; (v) product designs should address market failures; and (vi) it is possible to enhance financial capability, financial knowledge, skills, attitudes and behaviors through well-designed, targeted financial inclusion intervention. Financial inclusion is also revealed condition that not only cultural variable approach influencing financial inclusion but also utilizing digital technology to access financial services and educating financial literacy in rural area (Arun et al., 2015). However, the World Bank emphasized that financial inclusion and access to finance are different issues.

Financial inclusion is defined here as the proportion of individuals and firms that use financial services. The lack of use does not necessarily mean a lack of access. Some people may have access to financial services at affordable prices, but choose not to use certain financial services, while many others may lack access in the sense that the costs of these services are prohibitively high or that the services are simply unavailable because of regulatory barriers, legal hurdles, or an assortment of market and cultural phenomena (World Bank, 2014).

Poverty is one of the greatest problems affecting developing countries. Socioeconomic imbalances, created by both natural and artificial resource scarcity, restrict impoverished people's access to economic opportunities, limiting their 
purchasing power and empowerment. Environmental degradation is thus both a cause and effect of resource scarcity, as the poor are forced to seek increasingly environmentally and economically unsustainable methods of income generation, further marginalizing them (Effendi, 2013). The conception of poverty that is employed here draws on Simmel (1965) which analyzes the relationship between poor people and the society. Poverty alleviation is part of "the role that each concrete individual member of society performs". Therefore, "[t]he poor, as a sociological category, are not those who suffer specific deficiencies and deprivations, but those who receive assistance or should receive it according to social norms".

Following Simmel (1965), poverty means being in need relative to others in the same society, and relative to its expectations and norms. Post-development theorist Yapa (1997), conceptualizes poverty as consisting in global social relations, arguing that no conception of "poor" could exist without corresponding conceptions of "non-poor". Mediated through the production sphere, discourses of poverty and non-poverty generate recognition and acceptance of the material symptoms while simultaneously hiding the causes of the concrete phenomena, which are lumped together as "poverty" (Yapa, 1997).

Through the SDGs, every country is targeted to eradicate extreme poverty by the year 2030, which is currently measured as people living on less than $\$ 1.25$ a day (World Bank, 2014). As one of the efforts to achieve this objective, the authorities have started to strengthen the capacity of domestic financial institutions to encourage and expand access to banking, insurance and financial services for all. Likewise, according to Wulandari and Kassim (2016), IMFIs provides financial services not only for the poor but also for the poorest in the informal sector of the economy, which are usually being funded using external sources such as Zakat, Infaq and Shadaqah. Furthermore, another study finds that there are some opportunities capable of improving the economic conditions of the poor Muslim communities through IMFIs, based on the Islamic principle (Hassan et al., 2015).

\subsubsection{Previous Study}

An empirical study on access to Islamic microfinance programs in Bangladesh by Rahman (2010) revealed that clients significantly increased their household income, productivity of crops and livestock, expenditures, and employment. The author concluded that Islamic micro-investment may encourage more ethical and economically desirable behavior that would lead to poverty alleviation. In addition, according to Sirageldin (2000), Islamic ethics plays a positive role in supporting poverty alleviation programs based on promoting economic growth with productive equity. Obaidullah and Khan (2008) state that Islamic MFIs have a more comprehensive approach to poverty alleviation than conventional MFIs, since they are able to reach the poorest of the poor and provide them with access to financial services. Additionally, Sugema, Bakhtiar, and Effendi (2010) suggest that the performance of profit and loss sharing schemes, one of the staples of Islamic microfinance, can be further improved through the establishment of a risk-pooling mechanism that absorbs all the risk encountered by both institution and client, enabling greater fund distribution and reducing income disparity. 


\section{METHODOLOGY}

\subsection{Data}

There are two sources of data used in this research, namely primary and secondary data. Primary data is achieved through interview and questionnaire survey with BMT. The interview and questionnaire will be asked sequentially to the practitioners of BMT in Indonesia. Secondary data will be acquired from available literatures includes journals, books and relevant materials like statistical database and Islamic MFIs report

The sampling requirements for qualitative analysis are:

i. BMTs manager with more than two years experiences

ii. Have financial literacy in particularly financial inclusion implementation.

iii. Have a good financial statement

iv. Have a product for financing the poor such as Qardhul Hasan.

The rational of using PLS in this study are based on the following reasons. Firstly, the use of PLS-SEM for the present study is based on the nature of the study. The objective of this study is to explore the structural model of the roles of IMFIs by examining the wealth creation, alleviation of poverty and sustainability of IMFIs. Furthermore, PLS-SEM is the best appropriate for data analysis because the objective model is to measure the extension of model prediction. Hair et al. (2011) mentioned that the PLS-SEM is applied while the research is to explore or to extend an existing structural theory. PLS-SEM aims to measure the extent to which a construct in the research model predicts values in other construct of the research model.

Secondly, the reason for carrying out of PLS-SEM is based on characteristics and advantages for data analysis. PLS-SEM can explain model complexity with a small-sample size. It differs from the previous SEM that requires to adequate sample or a large number. On the other hand, PLS-SEM can obtain a high level of statistical power although the sample size is relatively small (Reinartz et al., 2009). Moreover, the other characteristic of PLS-SEM are related data properties. Different from covariance-based SEM (CB-SEM) that needs a multivariate normal data distribution from the sample data, PLS-SEM is still powerful even if the data is not normally distributed. Therefore, a total of thirty-four (34) managers of BMTs throughout the areas of Jakarta, Bogor, Depok, Tangerang and Bekasi (JABODETABEK), were selected as respondents. The study focused on the managers of the BMTs as respondents because they know the financial inclusion regulation, understand the goals of institutions and adapt the change of business environment. Data collection process lasted for about four months from June 2018 to September 2018. A total of 50 questionnaires were distributed equally to JABOTABEK areas, at the end, from data collection process, 34 questionnaires were suitably completed and judged useful for this research. This represents a response rate of 68 percent.

Before getting on further survey, questionnaire was tested for validity and reliability test. Cronbach's alpha test showed an adequate number for the questionnaire to be proceeded with a reliability value of 0.848 . Meanwhile, validity test for each question was done by looking at whether corrected item total correlation value exceeded r-table for 81 (83-2) which was 0.18 . The result obtained shows that all questions in the questionnaire had more than 0.18 in their corrected item-total correlation, thus were valid. 


\subsection{Model Development}

The effective of role of IMFIs towards alleviating poverty is elaborated through a model consist five latent variables. Those are Latent Exogenous Role of IMFIs towards Community Development (CD), Role of IMFI towards Financial Education (FE), Role of IMFI towards Islamic Values (IV) and Role of IMFI towards Financial Policies (PL). Likewise, Latent Endogenous Poverty Alleviation comprises Poverty Reduction (FI). The rest of 5 variables are dependent latent variables. All variables have been significantly proven in building construct. The structural model indicates the relationship among latest variables. in notation, they can be described in following equations (Wold, 1984).

$$
\eta=\beta \eta+\Gamma \xi+\varsigma
$$

Equation 1 shows relationship among latent variables, where:

$\eta$ (Eta) endogenous latent variable that contains Poverty reduction (FI).

$\xi$ (Ksi) exogenous latent variables. Such as Role of IMFI towards Community Development (CD), Role of IMFI towards Financial Education (FE), Role of IMFI towards Islamic Values (IV) and Role of IMFI towards Financial Policies (PL).

$\beta$ (Beta) structural coefficient from endogenous latent variable to another endogenous latent variable.

$\gamma$ (Gamma) structural coefficient from exogenous latent variable to endogenous latent variable.

$\varsigma$ (Zeta) structural error terms.

$x=\Lambda x \xi+\delta$

$y=\Lambda y \eta+\varepsilon$

Equations 2 and 3 show relationship between manifest and its latent variable ( $x$ for exogenous, $y$ for endogenous), where;

$\lambda$ (Lambda) loading between latent variable and its manifest variables

$\delta$ (Delta) measurement error for exogenous variable

$\varepsilon$ (Epsilon) measurement error for endogenous variable

By using SmartPLS 3.0, according to validity and reliability tests, significant constructs are Community Development (CD), Financial Education (FE), Islamic Values (IV) and Financial Policies (PL). Likewise, latent endogenous towards construct Poverty Alleviation (FI). The early model of this study searches 31 parameters with 5 latent variables.

\subsection{Method}

The Partial Least Square (PLS) is used to analyze the data collected in this study. The PLS is a part or an alternative of structural equation modeling. According to Sanchez (2013) specified that PLS is a set of methods for analyzing multiple relationship between various blocks of variables. According to Henseler et al. (2009) and Hair et al. (2012 - 2014), PLS-SEM is an analysis a variance-based of 
structural equation modeling. It is different from the first generation of structural equation modeling (SEM) as a covariance-based model. The PLS-SEM can run with a small-sized sample (Henseler, Ringle, \& Sinkovics, 2009).

Thus, the model is identified where data is smaller than predicted data which gives information minimum data is suitable for 34 samples in PLS model. It makes the degree of freedom become positive (predicted data-estimated parameters $>0$ ). The selecting variables derived from elements of financial inclusion that emphasize financial access to the poor and create the business opportunities, namely; financial knowledge, community development targeted, socio-cultural phenomena and financial policies. (World Bank, 2014)

Details of the model are shown in Figure 1.

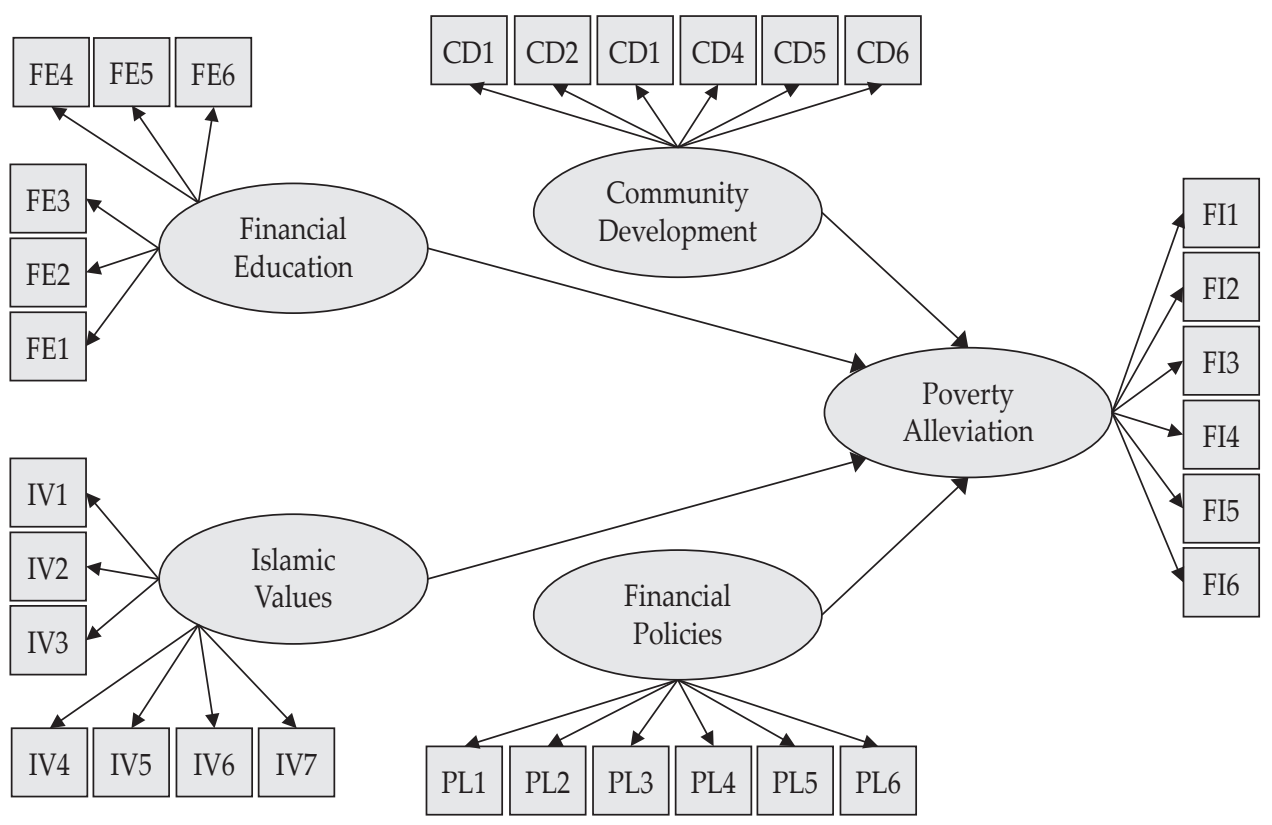

Figure 1.

Initial Model of Alleviating Poverty through Islamic Microfinance

\section{RESULTS AND FINDINGS}

\subsection{Results}

\subsubsection{Characteristic of Respondents}

Table 1 depicts the characteristics of respondents from survey questionnaire. It absolutely shows that 100 percent managers are male for managing BMT and more than fifty percent respondents are above forty years old (58.8\% respectively and $41.2 \%$ below forty). Likewise, by describing income data, $32.4 \%$ respondents have income more than ten million rupiahs, $29.4 \%$ between five and ten million, $23.5 \%$ between three and five million and last, $14.7 \%$ below five million rupiahs. Finally, by length of time working, $94.1 \%$ respondents work more than five years 
and $2.9 \%$ respondents work between three and five years. Also respondents work below three years are $2.9 \%$ respectively.

Table 2.

Characteristics of Respondents

\begin{tabular}{lccc}
\hline Variable & Cluster & Frequency & Valid Percent \\
\hline \multirow{3}{*}{ Gender } & Male & 34 & 100.0 \\
& Female & - & - \\
Age (Years old) & Total & 34 & 100.0 \\
& $29-39$ & 14 & 41.2 \\
& $\geq 40$ & 20 & 58.8 \\
& Total & 34 & 100.0 \\
\hline \multirow{2}{*}{ Income (Rp) } & $1-3$ Million & 5 & 14.7 \\
& $3.1-5$ Million & 8 & 23.5 \\
& $5.1-10$ Million & 10 & 29.4 \\
& $\geq 10$ Million & 11 & 32.4 \\
Length of Time Working & Total & 34 & 100.0 \\
(Years) & $1-3$ Years & 1 & 2.9 \\
& $3-5$ Years & 1 & 2.9 \\
\hline & $\geq 5$ Years & 32 & 94.1 \\
& Total & 34 & 100.0 \\
\hline
\end{tabular}

\subsubsection{Fitness Tests and Overall Results}

This section explains fitness tests and overall results which comprehend variables influencing poverty alleviation namely; Community Development, Financial Education, Islamic Values and Financial Policies.

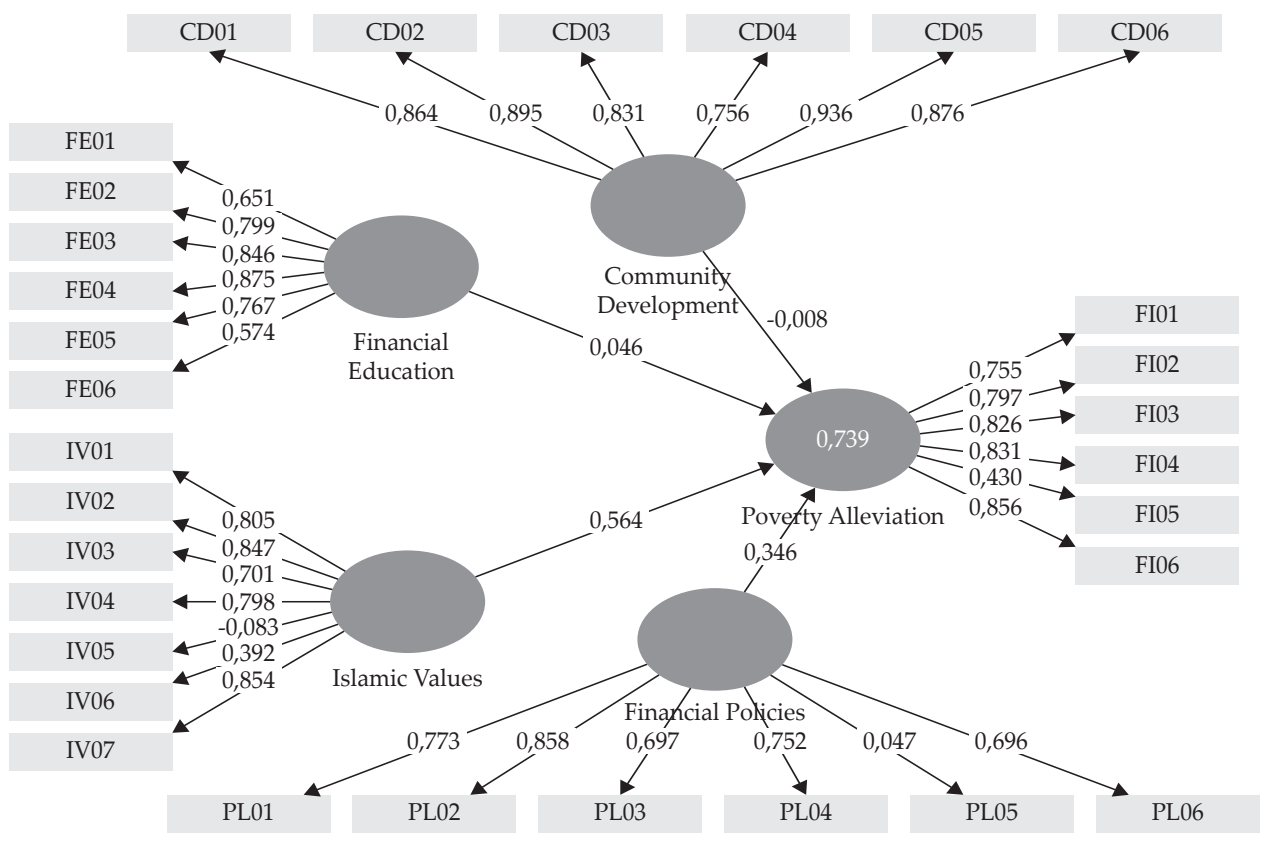

Figure 2.

Poverty Alleviation Model 
Figure 2 shows that path coefficient value of latent exogenous variables affects latent endogenous variable. Value path coefficient Community Development (CD) negative means latent exogenous $C D$ has negative impact towards latent endogenous poverty alleviation. Whilst, another latent exogenous variable such as Financial Education, Islamic Values and Financial Policies were positive. It means those latent exogenous variables have positive impact with Financial Education 0.046, Islamic Values 0.564 and Financial Policies 0.346 .

On the other hand, R-Square illustrates that latent exogenous variables simultaneously affect latent endogenous variable 0.739 or this relationship can be explained that latent endogenous variable has been affected latent exogenous variables $73.9 \%$.

Table 3.

Path Coefficient and R-Square

\begin{tabular}{|c|c|c|c|}
\hline \multicolumn{2}{|c|}{ Structural Equation } & \multirow[b]{2}{*}{ Path coefficient } & \multirow[b]{2}{*}{$\mathbf{R}^{2}$} \\
\hline $\begin{array}{l}\text { Latent endogenous } \\
\text { variable }\end{array}$ & $\begin{array}{c}\text { Latent exogenous } \\
\text { variable }\end{array}$ & & \\
\hline \multirow{4}{*}{ Poverty Alleviation (FI) } & $\begin{array}{l}\text { Community Development } \\
\text { (CD) }\end{array}$ & -0.008 & \multirow{4}{*}{0.739} \\
\hline & Financial Education (FE) & 0.046 & \\
\hline & Islamic Values (IV) & 0.564 & \\
\hline & Financial Policies (PL) & 0.346 & \\
\hline
\end{tabular}

Table 4 exemplified that composite reliability all of constructs more than p-standard 0.6. It means that internal consistency measurement both of those latent variables were reliable. Likewise, Average Variance Extracted (AVE) all constructs show values more than 0.5 except Islamic Values (0.483) and Financial Policies (0.479). It means convergent validity measurement both of construct were less-represented indicators in its variable. Therefore, Cronbach Alpha shows that to measure ideal reliability all latent variables need to achieve value more than p-standard 0.6. All measurement shows that all value more than 5. It means all latent variables have ideal reliability.

Table 4.

Construct Reliability and Validity

\begin{tabular}{lcccc}
\hline Construct & $\begin{array}{c}\text { Composite } \\
\text { Reliability }\end{array}$ & AVE & Cronbach Alpha & Fit/Un-fit \\
\hline Community & 0.945 & 0.742 & 0.930 & Fit \\
Development (CD) & 0.889 & 0.577 & 0.854 & Fit \\
Financial Education (FE) & 0.837 & 0.483 & 0.752 & Fit \\
Islamic Values (IV) & 0.824 & 0.479 & 0.749 & Fit \\
Financial Policies (PL) & 0.890 & 0.583 & 0.848 & Fit \\
Poverty Alleviation (FI) & & &
\end{tabular}


To measure structural model, it can be seen that following $\mathrm{Q}^{2}$ value:

$$
\begin{aligned}
\mathrm{Q}^{2} & =1-\left(1-\mathrm{R}^{2}\right) \\
& =1-(1-0.739)=0.739
\end{aligned}
$$

It means the structural model is fit with data due to $\mathrm{Q}^{2}$ value towards point 1 which represent the structural model is valid and reliable. This result shows all indicators were valid and reliable that reflect all latent variables with structural model test was fit. All latent exogenous variables simultaneously significant affect latent exogenous variable.

\subsubsection{Measurement Model}

By analyzing data, this study uses software SmartPLS3.0 to examine latent variables and construct model role of IMFI towards alleviating poverty. Loading factor more understand to be interpreted than loading weight value. This can be seen on following Table 5. The outer loading highlights how latent exogenous variables influence its manifests/indicators, for example Community Development (CD) variable influences its indicator (CD01) is 0.864 . In general, each latent exogenous variables have positive point to the dimensions except Islamic Values (IV) to its dimension IV05 is -0.086 and Financial Policies (PL) to its dimension PL05 is -0.060 . It can be conclude that each latent exogenous variables reflect its dimensions to influence poverty alleviation variables.

Table 5.

Outer Loading

\begin{tabular}{lccccc}
\hline \multicolumn{1}{c}{ Variable } & Sub variable & $\begin{array}{c}\text { Entire } \\
\text { sample } \\
\text { estimate }\end{array}$ & $\begin{array}{c}\text { Mean of } \\
\text { sub-sample }\end{array}$ & $\begin{array}{c}\text { Standard } \\
\text { Deviation }\end{array}$ & T-Statistic \\
\hline \multirow{5}{*}{ Community } & CD01 & 0.864 & 0.845 & 0.127 & 6.789 \\
Development (CD) & CD02 & 0.895 & 0.873 & 0.137 & 6.556 \\
& CD03 & 0.831 & 0.828 & 0.091 & 9.081 \\
& CD04 & 0.756 & 0.749 & 0.125 & 6.055 \\
& CD05 & 0.936 & 0.914 & 0.131 & 7.161 \\
& CD06 & 0.876 & 0.846 & 0.161 & 5.442 \\
\hline \multirow{3}{*}{ Financial } & FE01 & 0.617 & 0.595 & 0.216 & 3.013 \\
Education (FE) & FE02 & 0.454 & 0.735 & 0.220 & 3.641 \\
& FE03 & 0.349 & 0.813 & 0.152 & 5.568 \\
& FE04 & 0.461 & 0.833 & 0.186 & 4.701 \\
& FE05 & 0.522 & 0.744 & 0.140 & 5.467 \\
& FE06 & 0.839 & 0.542 & 0.223 & 2.576 \\
\hline Islamic Values (IV) & IV01 & 0.447 & 0.782 & 0.099 & 8.103 \\
& IV02 & 0.466 & 0.855 & 0.062 & 13.652 \\
& IV03 & 0.322 & 0.644 & 0.205 & 3.410 \\
& IV04 & 0.336 & 0.797 & 0.072 & 11.015 \\
& IV05 & -0.086 & -0.069 & 0.318 & 0.262 \\
& IV06 & 0.147 & 0.368 & 0.221 & 1.772 \\
& IV07 & 0.509 & 0.862 & 0.044 & 19.512 \\
\hline
\end{tabular}


Table 5.

Outer Loading (Continued)

\begin{tabular}{lccccc}
\hline \multicolumn{1}{c}{ Variable } & Sub variable & $\begin{array}{c}\text { Entire } \\
\text { sample } \\
\text { estimate }\end{array}$ & $\begin{array}{c}\text { Mean of } \\
\text { sub-sample }\end{array}$ & $\begin{array}{c}\text { Standard } \\
\text { Deviation }\end{array}$ & T-Statistic \\
\hline \multirow{3}{*}{ Financial Policies } & PL01 & 0.228 & 0.769 & 0.103 & 7.521 \\
$($ PL) & PL02 & 0.481 & 0.852 & 0.086 & 10.037 \\
& PL03 & 0.276 & 0.687 & 0.145 & 4.810 \\
& PL04 & 0.669 & 0.726 & 0.101 & 7.449 \\
& PL05 & -0.060 & 0.062 & 0.335 & 0.141 \\
& PL06 & 0.532 & 0.691 & 0.113 & 6.164 \\
\hline \multirow{3}{*}{ Poverty Alleviation } & FI01 & 0.134 & 0.732 & 0.151 & 5.009 \\
(FI) & FI02 & 0.385 & 0.796 & 0.079 & 10.061 \\
& FI03 & 0.522 & 0.842 & 0.060 & 13.661 \\
& FI04 & 0.596 & 0.819 & 0.061 & 13.627 \\
& FI05 & 0.367 & 0.442 & 0.280 & 1.535 \\
& FI06 & 0.335 & 0.857 & 0.041 & 21.119 \\
\hline
\end{tabular}

Table 6 shows that path coefficient value of latent exogenous variables affects latent endogenous variable. Value path coefficient Community Development (CD) negative means latent exogenous $\mathrm{CD}$ has negative impact towards latent endogenous poverty alleviation. Whilst, another latent exogenous variable such as Financial Education, Islamic Values and Financial Policies were positive. It means those latent exogenous variables have positive impact with Financial Education 0.046, Islamic Values 0.564 and Financial Policies 0.348. On the other hand, R-Square illustrates that latent exogenous variables simultaneously affect latent endogenous variable 0.739 or this relationship can be explained that latent endogenous variable has been affected latent exogenous variables $73.9 \%$. It can be conclude that Community Development variable is not significant to influence poverty alleviation. However, Financial Education variable, Islamic Values variable and Financial Policies variable are significant to influence poverty alleviation. 
Table 6.

Path Coefficient and R-Square

\begin{tabular}{|c|c|c|c|}
\hline \multicolumn{2}{|c|}{ Structural Equation } & \multirow[b]{2}{*}{ Path coefficient } & \multirow[b]{2}{*}{$\mathbf{R}^{2}$} \\
\hline $\begin{array}{l}\text { Latent endogenous } \\
\text { variable }\end{array}$ & Latent exogenous variable & & \\
\hline \multirow{4}{*}{ Poverty Alleviation (FI) } & Community Development (CD) & -0.008 & \multirow{4}{*}{0.739} \\
\hline & Financial Education (FE) & 0.046 & \\
\hline & Islamic Values (IV) & 0.564 & \\
\hline & Financial Policies (PL) & 0.346 & \\
\hline
\end{tabular}

Table 7 exemplified that composite reliability all of constructs more than p-standard 0.6. it means that internal consistency measurement both of those latent variables were reliable. Likewise, Average Variance Extracted (AVE) all constructs show values more than 0.5 except Islamic Values (0.483) and Financial Policies (0.479). it means convergent validity measurement both of construct were less-represented indicators in its variable. Therefore, Cronbach Alpha shows that to measure ideal reliability all latent variables need to achieve value more than p-standard 0.6. All measurement shows that all value more than 5. It means all latent variables have ideal reliability.

Table 7.

Construct Reliability and Validity

\begin{tabular}{lcccc}
\hline Construct & $\begin{array}{c}\text { Composite } \\
\text { Reliability }\end{array}$ & AVE & $\begin{array}{c}\text { Cronbach } \\
\text { Alpha }\end{array}$ & Fit/Un-fit \\
\hline Community Development (CD) & 0.945 & 0.742 & 0.930 & Fit \\
Financial Education (FE) & 0.889 & 0.577 & 0.854 & Fit \\
Islamic Values (IV) & 0.837 & 0.483 & 0.752 & Fit \\
Financial Policies (PL) & 0.824 & 0.479 & 0.749 & Fit \\
Poverty Alleviation (FI) & 0.890 & 0.583 & 0.848 & Fit \\
\hline
\end{tabular}

To measure structural model, it can be seen that following $\mathrm{Q}^{2}$ value:

$$
\begin{aligned}
\mathrm{Q}^{2} & =1-\left(1-\mathrm{R}^{2}\right) \\
& =1-(1-0.739)=0.739
\end{aligned}
$$

The results suggest that the structural model is fit with data due to $\mathrm{Q}^{2}$ value towards point 1 which represent the structural model is valid and reliable. This result shows all indicators were valid and reliable that reflect all latent variables with structural model test was fit. All latent exogenous variables simultaneously significant affect latent exogenous variable. 


\section{CONCLUSION}

\subsection{Conclusion}

With the aim of assessing the efforts of the BMT as an Islamic MFI in alleviating poverty, this study conducted a survey questionnaire among 34 managers of BMTs in the areas of Jakarta, Bogor, Depok, Tangerang and Bekasi. A questionnaire is designed to seek the respondents' feedback on role of IMFIs in alleviating poverty with its latent exogenous variables, namely community development, financial education, Islamic values and financial policies. Several interesting findings emerge from this study. Firstly, the variable community development variable was found to be negatively related, thus having negative impact towards latent endogenous poverty alleviation. Community development variable in this study has been shown to be negatively affecting poverty alleviation. However, financial education has been proven to have a positive relationship in alleviating poverty, similarly Islamic values and financial policies have also been found to be significantly proven to alleviate poverty. It ultimately affects the outcome indicators that is represented by whole model in poverty alleviation.

\subsection{Recommendation}

In view of these findings, the study recommends that improving financial education as a major effort to increase financial inclusion especially on ways in accessing financial services would be significant if IMFIs stakeholders routinely provide training or financial learning to their client. At the same time, strengthening the Islamic values could be delivered in small-group economic empowerment. This could also avoid the poor from involving in interest-based conventional microcredit, which is prohibited in Islam. Last but not least, socialization of financial policy including financial inclusion simultaneously has to be carried into their client due to change of regulation. Academicians and practitioners should endorse Islamic principles related to microfinance industry actively, not only financial matters, but regularly also about social knowledge and behavioral matters. Since the result of this study shows that community development gives negative relationship, yet the others are positive. Therefore, psychological and socio-economy aspects should be included in their product offerings and program implementations.

These results also endorses the recommendations for managers of BMT as a practitioner and OJK as a regulator related to poverty alleviation in term of quality microfinance services.

1. Islamic microfinance institutions, in particular BMT should develop well management skill, certainly for their human resource to penetrate microfinance services in remote area. Moreover, BMTs should cultivate program of financial education or literacy to their borrowers in understanding microfinance namely financial statement, cash flow and risk management in microbusiness. For example, understanding meticulous financing products and benefit saving are needed to engage with financial inclusion program. In addition, BMTs should optimize Islamic values through monthly Islamic studies meeting for supporting their business with Islamic norms and last, increasing Community Development that link to association of BMT (APEX BMT) would help BMTs facing the competition in informing new regulation and involving subsidize or CSR scheme program from donators. 
2. Financial authorities services (OJK) should identify financial inclusion regulation that could influence positive impact to customer increase and conduct some policies of micro financing sustainability namely analysing the appropriate policies with considering role of IMFIs in improving financial inclusion and detecting gap in financial inclusion policies between IMFIs and commercial banks. However, collaboration micro financing scheme between IMFIs and commercial banks could be one alternative to support IMFIs by struggling in micro finance competition. Last but not least, in term of role of IMFIs in improving financial inclusion, regulator should be able to gather all micro finance stakeholders in hearing what the market needed.

\section{REFERENCES}

Allen, F., Demirguc-Kunt, A., Klapper, L., \& Martinez Peria, M. S. (2016). The Foundations of Financial Inclusion: Understanding Ownership and Use of Formal Accounts. Journal of Financial Intermediation, 27(2016), 1-30. https://doi. org/10.1016/j.jfi.2015.12.003

Arun, T., \& Kamath, R. (2015). Financial Inclusion: Policies and Practices. IIMB Management Review, 27(4), 267-287. https://doi.org/10.1016/j.iimb.2015.09.004

Beck, T., Senbet, L., \& Simbanegavi, W. (2015). Financial Inclusion and Innovation in Africa: An Overview. Journal of African Economies, 24. https://doi.org/10.1093/ jae/eju031

Effendi, J. (2013). The Role of Islamic Microfinance in Poverty Alleviation and Environmental Awareness an Pasuruan, East Java, Indonesia.

F. Hair Jr, J., Sarstedt, M., Hopkins, L., \& G. Kuppelwieser, V. (2014). Partial Least Squares Structural Equation Modeling (PLS-SEM). European Business Review, 26(2), 106-121. https://doi.org/10.1108/EBR-10-2013-0128

Hassan, A., Kumar, N., \& Sinclair, S. (2015). Humanomics Financial Inclusion of The Poor: From Microcredit to Islamic Microfinancial Services Financial Inclusion of The Poor: From Microcredit to Islamic Microfinancial Services. Humanomics Journal of Financial Economic Policy Iss Humanomics Iss International Journal of Sociology and Social Policy, 3112(11), 354-371. https:/doi. org/10.1108/H-07-2014-0051

Henseler, J., Ringle, C. M., \& Sinkovics, R. (2009). The Use of Partial Least Squares Path Modeling in International Marketing. Advances in International Marketing, 20, 277-319. https://doi.org/10.1108/S1474-7979(2009)0000020014

Ismail, W. bin M. C. H. A. G. B. (2014). Improving the Effectiveness of Islamic Micro-Financing Learning from BMT Experience. Humanomics, 26. https:/doi. org/10.1108/08288661011025002

Peng, D. X., \& Lai, F. (2012). Using Partial Least Squares in Operations Management Research: A Practical Guideline and Summary of Past Research. Journal of Operations Management, 30(6), 467-480. https://doi.org/10.1016/j. jom.2012.06.002

Rahim, A., \& Rahman, A. (2007). Islamic Microfinance: A Missing Component in Islamic Banking. 2, 38-53. Kyoto, Japan: Kyoto Bulletin of Islamic Area Studies.

Reinartz, W., Haenlein, M., \& Henseler, J. (2009). An Empirical Comparison of the Efficacy of Covariance-based and Variance-based SEM. International 
Journal of Research in Marketing, 26(4), 332-344. https://doi.org/10.1016/j. ijresmar.2009.08.001

Santoso, B., \& Ahmad, K. (2016). Islamic Microfinance Branchless Banking Model in Indonesia. Intellectual Discourse, Special Issue.

Wold, S. (1984). The partial. Society for Industrial and Applied Mathematics, 5(3), 735743.

World Bank. (2014). Financial Inclusion, Global Financial Development Report 2014. https://doi.org/10.1596/978-0-8213-9985-9

Yapa, L. (1997). On “What Causes Poverty? A Postmodern View.” Main, 87(4), 709-716. 
This page is intentionally left blank 